\title{
The Importance of Industry in Modern Economies of the Globalized World in the 21st Century
}

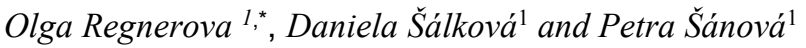 \\ ${ }^{1}$ Czech University of Life Sciences, Faculty of Economics and Management, Department of Trade \\ and Finance, Kamycka 129, 16500 Praha 6 - Suchdol, Czech Republic
}

\begin{abstract}
.
Research background: The classic explanation about the structure of economies stipulates that, as societies advance, their economy gradually shifts towards the tertiary sector where the added value is the highest. While this logic proved to be empirically true during the last centuries, it nonetheless comes with significant issues in the long run. The need for manufactured products, which is constantly growing due to global economic development and a growing population, must still be addressed by an industrial base around. This leaves only two options open: 1 . Some countries have to lag behind the rest of the world in terms of global economic development or 2. Developed countries will have to devote part of their labor and capital investment to (re) building capable industrial capacity.

Purpose of the article: The aim of the article is to point out the influence of globalization on the position of production structures in the context of the global crisis.

Methods: Comparative method, definition of the object of comparison and determination of the goal of comparison and determination of criteria for own analysis of relevant sources, induction, deduction, generalization.

Findings \& Value added: The only way to maintain enough industrial capacity to answer the demand in a globalized world without having some countries lagging behind will be to redistribute the production capabilities among the countries. This would make the economic playfield more even and would also have several side benefits regarding global environmental and political issues including unexpected crises such as pandemic period coronavirus.
\end{abstract}

Keywords: globalization; industrial capacity; economic development; pandemic period; global needs

JEL Classification: $A 1 ; F 6 ; O 1$

\footnotetext{
${ }^{*}$ Corresponding author: oregnerova@pef.czu.cz
} 


\section{Introduction}

Globalization, the process by which national economies have integrated into a vast interconnected global economic system, has led to a tremendous growth in global trade and international business. As a result, global trade and GDP have grown in tandem recently, both increasing by 26 per cent during $2008-18$ period [1].

Economic development is the basis for the well-being of both the individual country and the community as a whole, and it is important to notice the patterns of this development. This would help to formulate further targeted development strategies that take into an account the level of economic development achieved by the countries [2].

One of the earliest and most central insights of the literature on economic development is that development entails structural change. The countries that manage to pull out of poverty and get richer are those that are able to diversify away from agriculture and other traditional products. As labor and other resources move from agriculture into modern economic activities, overall productivity rises and incomes expand. The speed with which this structural transformation takes place is the key factor that differentiates successful countries from unsuccessful ones [3].

The sectoral structure of production of market economy countries characterizes the economic maturity of countries and helps to explain economic processes in the light of globalization.

The transition from agriculture to industrial production, which originally began in England in the 18th century and which later spread to all the developed countries of the world, was characterized as an industrial revolution. The transition from an economy based on industrial production to an economy with a developed service sector, which followed in all developed economies, took place much more smoothly. However, this has caused major changes in society, employment and the entire development of the countries' economies.

The founders of the original theory of the three sectors in economics are a pair of economists Colin Clark and Allan Fisher. Allan Fisher studied the New Zealand economy, where he was active, before World War II. In 1939, he published the article "Production, primary, secondary and tertiary", in which he first used the term "tertiary" in statistical research in the New Zealand and Australian economies [4]. British statistician and economist Colin Clark found partial inspiration in his work. He published his major work in the field of economic sectors in 1940, entitled "Conditions of Economic Progress" [5].

In his 1949 book Le Grand Espoir du XXe siècle, the French economist Jean Fourastié envisaged a future in which advanced economies would be mainly driven by services and nonindustrial companies. He based this prediction on the empirical observation of this trend in developed countries, building upon the division of economies in three sectors devised by Colin Clark earlier. This prediction stood up well to the test of time, but not for the reason Clark and Fourastié anticipated. In their original prediction, they assumed that increased productivity would allow the industry to perform at the same level with less factors of production [6].

In the 1960s, according to H. J. Pohl, it is appropriate to use more criteria for dividing the national economy into three sectors (the value of the income elasticity of demand, or the extent of technical progress). However, even these criteria do not lead to satisfactory results. H. J. Pohl pointed out that over time some economic sectors are assigned to different sectors, or it is clear that the boundaries between individual sectors are not clearly defined (for example, for many productions the question arises whether they belong to construction or transport) [7].

Many objections and discussions in the past stemmed from insufficiently statistically supported data on the national economy. Over time, and especially with the development of computer technology, economic statistics have unified and grown. Not only in width but also 
in depth. For example, the establishment of the OECD in 1961, which brought about a unified ISIC system, made a significant contribution to this. Authors in the 1970s and authors of later periods thus had a much better basis for comparative analyzes within a single country, or even in an international comparison.

In the 1970s and 1980s, Professor H. Katouzian of the University of Kent in Canterbury also dealt with the tertiary sector, which he consistently called the "services" sector. He monitored the development of the tertiary sector on a sample of developed countries on the one hand and compared it with the development of the tertiary sector of backward countries on the other. He examined it from two different aspects [8].

The pair of authors examine the transition to the tertiary sector of 14 European countries - old EU members in the period from 1970 to 2005 from a mathematical point of view, while they are also interested in more detail on the division of the tertiary sector into different groups of services. Among other things, in their work [9] they confirm Katouzian's theory that the share of employment in the primary sector is inversely proportional to per capita income, while in both other sectors the ratio is direct. Convergence analyzes show that the gradual equalization of per capita incomes in the old EU has led to a convergence of the share of individual groups of services, as measured across Europe. At the same time, however, they acknowledge that the convergence of the share of the secondary sector is much more pronounced, thanks to industrial integration and a more flexible industrial market compared to services. The mentioned authors also bring a critique of the classical three-sector model and mention several attempts to divide the tertiary sector: to implement a quarterly sector, including ICT services (information and communication technologies).

\section{Data and Methods}

However, there is empirically that developed countries did not follow this trend, and that their shift to service-based economies was accompanied by a significant dwindling of their industrial capacity. Instead of relying on their higher productivity, these countries simply exported their manufacturing needs to countries in which the factors of production, and mainly labour, were cheaper. This trend was possible for decades because weaker economies where there to produce goods when other countries were progressing economically speaking, and giving up on their industrial capacities.

This is unlikely to be sustainable on the long run, as the number of under-developed countries is finite and diminish while the demand for manufactured goods is rising, precisely because these countries are progressing. We will discuss the usual view that developed economies run almost solely on their third sector, and we will try to find a way out of this logical deadlock.

The current trade war between the United States and China was largely mediatized, nearly no coverage was made of the other great trade war unfolding since the early 2010s in Southern Asia. Countries such as Vietnam, Thailand, Myanmar or the Bangladesh have taken on their own war with the Chinese giant, trying to undercut production price for most of the common item that westerners buy a masse from Chinese-supplied brands.

While China has largely maintained its industrial dominance over the rest of the world in the last few years, it is nowadays facing the same challenges with regard to this industrial base than the US, Russia, France, the U-K and other developed economies faced in the late 1970s. As a result, Chinese industrial companies have lost some competitiveness to their foreign competitors, enabling the trade war mentioned above.

Still an industrial power before anything else, China is nonetheless moving in the direction of a more balanced economy, centred not only on manufactured goods production and heavy industry, but also on services, such as banking and insurance services, tourism or administration. As the Chinese exports accounted for more than half of the global 
manufacturing output in 20152 (by comparison with around 3\% in 1990), this raises the question of how the production and supply of these goods will be continued if China keeps downsizing its industrial base.

Between 2010 and 2020, the global demand for manufactured goods have increased by more than $25 \%$, owing mainly to the new economic giants such as India or Brazil. This demand will have to be fulfilled, which is why the closing of the Chinese "world's factory" could create tensions on the world's economy.

That all countries want to progress is obviously evident. If that progress if linked to a reduction in industrial capacity, how will the world be supplied in manufactured goods? There are mainly two options. The first one, the most unpleasant, is that some countries would be forced to lag behind the rest of the world and be used as the new "world factories". These countries would produce all the goods needed for the rest of the world, but doing so would prevent them from ever reaching the economic development phase where they could switch to the production of high added value goods and services.

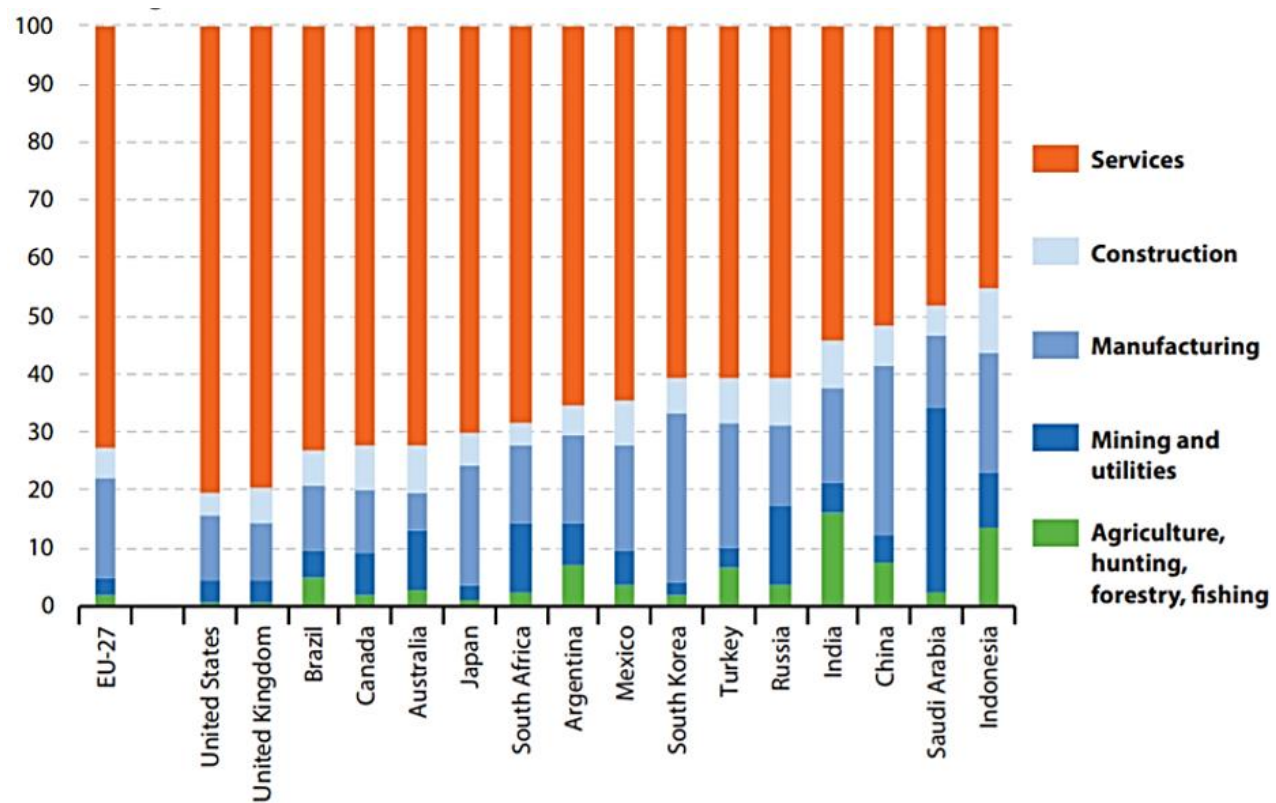

Fig. 1. Gross value added by economic activity, 2018 (\% of gross value added). The United Nations Dept. of Economic and Social Affairs, Statistics Division.

Figure 1 illustrates the economic structure in the G20 economies, using national accounts data to group economic activities into five broad headings based on the ISIC Rev.3 classification. In 2018, services contributed at least $70 \%$ of the total gross value added in the economies of the United States, the United Kingdom, Brazil, the EU-27, Canada, Australia and Japan. In all of the other G20 countries, services were also the largest of the five activity groupings shown and accounted for more than half of total gross value added except in Saudi Arabia (48.1\%) and Indonesia (45.2\%). Manufacturing was the second largest activity.

In value added terms in most of the G20 members. Exceptions were Saudi Arabia, Australia and Russia where mining and utilities was the second largest activity. India and Indonesia were the only G20 members where agriculture, hunting, forestry, fishing contributed more than one tenth of total gross value added and Indonesia was the only one where construction contributed more than one tenth of total gross value added [10]. 
One might wonder why countries would be willing to stay behind in term of economic development when compared with the rest of the world. Cynically enough, they might not have the choice. Consider the following situation: Country $\mathrm{A}$ is producing all the manufacturing goods for the rest of the world.

The rest of the world is more advanced economically speaking, and has shifted from a secondary sector-based economy to a third second-based one. It has retained little industrial knowledge, and only for the most advanced or strategic products. As the demand from the rest of the world to Country A for manufactured goods increases, the Country A progresses along the economic development scale, and starts downsizing its industry to switch to more the more profitable (and desirable socially speaking) service sector. However, as its ability to produce goods and supply the rest of the world decreases, the world as a whole enters an economic contraction phase (goods are not longer supplied to the rest of the world in sufficient quantities, the rest of the world can't maintain its own economic activities).

Country A now finds itself in a situation where not only does it supplies less industrial products than before, but it also cannot sell its services. The situation is therefore worse than when it was fully invested in industrial production. We see here the creation of an equilibrium point around which the structure of Country A's economy must revolve in order to maintain the overall balance. Instead of trying to improve its situation by moving to the production of services, Country A cannot do anything but trying to minimize its burden by fine-tuning its economy to the precise point where it supplies enough industrial goods to keep the world's economy running while at the same producing as much services as possible.

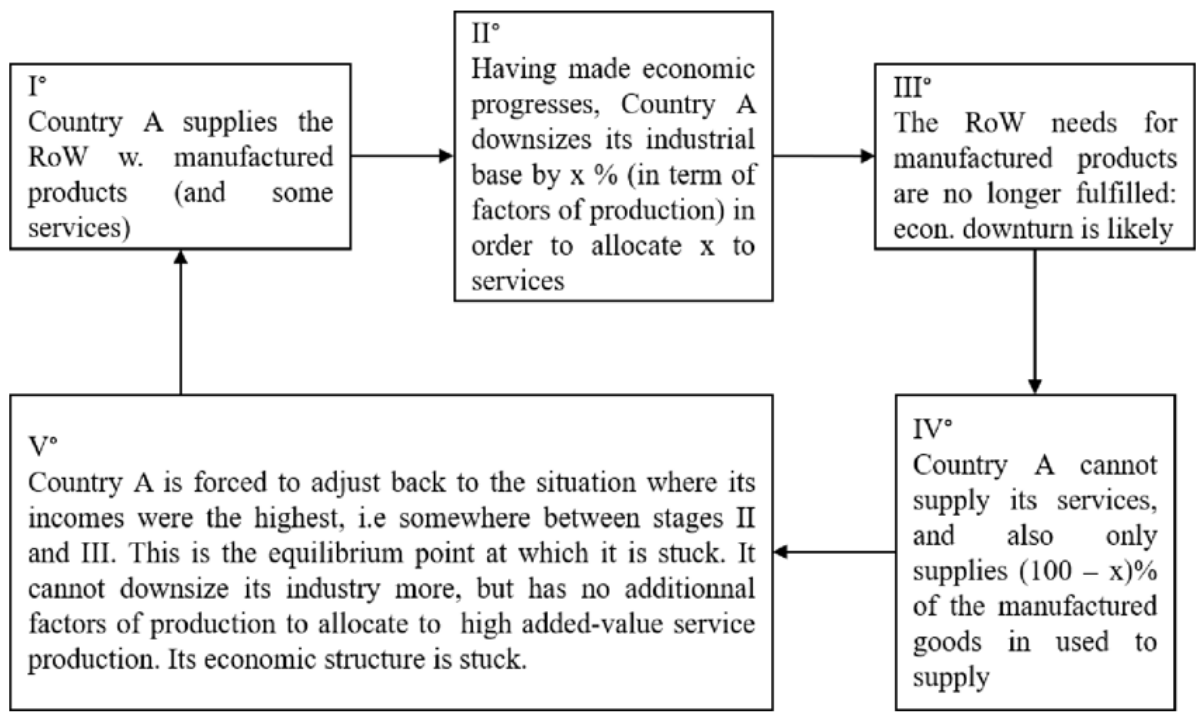

Fig. 2. The vicious circle forcing Country A to keep producing manufactured goods.

\section{Results and Discussion}

This situation can be accepted by such countries willing to sacrifice their would-be service industry in order to focus on supplying the world with services. If no country is willing to do the job, then we will see a rush from developing countries not to be the last to switch to a third-sector based economy.

The second way that the world could follow to avoid a situation where industrial production would not be sufficient to fulfil the global needs is to re-scatter the industrial 
facilities in all countries, resulting in economic structures akin to what the world saw between the 1950 s and the 1990s.

We contend that this is the best overall solution. It should be noted that technological progress would play a large role in justifying the relocation of industrial competencies in developed countries. Thanks to technological advances, productivity would be higher than before in the industry, which would make for lower factor of production needs for a similar output. The same production levels could be reached while still maintaining a significant part of the population in service jobs.

It is obvious that there are significant differences among variables used in various models and that for different countries with different type of economy should be developed a unique model with appropriate variables [11].

National policies need to be complemented by more effective international cooperation in order to achieve shared goals, particularly in the areas of climate change, international trade and finance. As the global economic balance is shifting from the European Union, the United States and other developed countries towards China, India and other developing countries, global economic decision-making power is shifting as well. Global cooperation mechanisms will need to recognize this shifting balance while continuing to allow the underrepresented to be heard[12]. China invested heavily in a stimulus package that included a significant focus on renewable energy and this build up precipitated growth in relevant industries and reductions in production costs that benefited companies and communities around the world [13].

However, even when considering technological progress, it would require strong incentives to relocate industrial facilities in developed countries. Fortunately, some of these incentives already exists today. Along those, the exogenous risks associated with the relocation of nearly all industries abroad were clearly highlighted with the Covid-19 crisis we are currently living, with numerous companies facing difficulties because their supply chain in China (or, more largely, in Asia) is struggling to keep up with the demand since most plants were shut down for a while, while the rest of the world was not impacted yet.

Globalization promotes specialization according to comparative advantage. Here there is another potentially important difference among countries. Some countries - many in Latin America and Africa - are well-endowed with natural resources and primary products. In these economies, opening up to the world economy reduces incentives to diversify towards modern manufactures and reinforces traditional specialization patterns. Some primary sectors such as minerals do operate at very high levels of labour productivity. The problem with such activities, however, is that they have a very limited capacity to generate substantial employment.

In economies with a comparative advantage in natural resources, we expect the positive contribution of structural change associated with participation in international markets to be limited. Asian countries, most of which are well endowed with labour but not resources, have a natural advantage here. The rate at which structural change in the direction of modern activities takes place can also be influenced by ease of entry and exit into industry and by the flexibility of labour markets [3].

It is tempting perhaps to extrapolate current growth rates to figure out how the global economy will be reshaped in the next decades. On this measure, an $8 \%$ growth rate in China over the next 40 years would produce a 21 -fold increase in the Chinese economy by 2050 , and a $2 \%$ growth rate in the European Union would result in $21 \%$ economic growth over the same period. However, back-of-the-envelope calculations based on past trends can be extremely misleading [14]. Local production capabilities would have meant lower disruption of the world economy, as the companies would have been able to produce more and for longer before having to shut down. As it stands now, China was closed while the western world was 
still demanding products, which reversed once the virus reached Europe and the US and China restarted its production lines.

A high volume of intra-industry trade can be expected even between economies which are identical in all respects and thus between which no trade would be predicted on the basis of comparative advantage [15].

During times like these, reactive collaboration and/or cooperation (e.g., shifting the risk and uncertainty to the firms' partners) is the most common strategy used by firms to handle environmental or industry uncertainty. Firms may also try to avoid uncertainty when the level of [16], environmental and industry uncertainties is much greater than their worst expectations.

One of the important facts omitted here is globalization and its effects on growth: the decline of trade barriers, the decline in transportation and communication costs, the rise of vertical supply chains [17]. Significant changes in macroeconomic development may arouse new motives and incentives to enterprises, forcing them to manage earnings in order to maintain their financial position. State authorities, auditing and accounting companies should use all possible sources to identify the manipulation techniques in order to protect the market, investor and stakeholder from financial risks caused by crooked financial reports [18].

The development of new technologies, including digital and robotic production and the provisioning of "flying (i.e., temporary, localized) factories," are challenging conventional practices, offering productivity improvements and potential environmental benefits in the manufacture and use of buildings [19].

Analysis of Nobuya Haraguchia Bruno reveals that successful industrialization is driven by a combination of factors, including a country's initial economic conditions, factor endowments and other characteristics, such as demography and geography. We also show that other variables that policymakers can control play a crucial role. This includes, among others, the promotion of investments (both public and privately funded) and education; the management of trade and capital openness; financial sector development and the promotion of both macroeconomic and institutional stability [20].

Scientists around the world are in a race against time to develop a vaccine and find the right drugs to treat the debilitating symptoms of this unique disease as it continues to wreak havoc on the global economy. Most countries have issued stay in-shelter orders to their citizens, locked down their borders to inbound and outbound travel, and restricted the flow of everything except essential commodities such as food and medicine [21].

The spread of the COVID-19 has both direct and indirect consequences which are expected to prove to be even more pervasive over time. The pandemic virus has resulted in the deaths of thousands of people, as well as the unemployment of millions of employees and workers [22].

Another incentive to relocate would be the threat posed by global warming. With shorter supply lines and simplified logistics, the environmental impact of economic activities would be significantly lowered. Finally, ideological and political disagreements between producing and importing countries are also advocating in favour of such a move.

The recent example of Huawei's alleged involvement in spying activities for the Chinese government, and the lack of a suitable western network hardware manufacturer to compensate for the eviction of Huawei, is a prime example of such issues. We can expect that the COVID-19 pandemic will prompt business managers and policy makers to reexamine prevailing globalized systems of production based on complex value chains and the international shipment of billions of components and likely prompt establishment of new relationships and supply configurations. The coronavirus outbreak exposes the vulnerability of overreliance on just-in-time (JIT) and lean delivery systems. Separate from current 
travails, there has been a long-running debate about whether JIT systems - which can be efficient in terms of resources and waste - are also environmentally sound [23].

As is evident by the rapid global spread of Covid-19, the nature and level of uncertainty is potentially amplified due to the potential disconnect that each of these elements may have across different national boundaries. Similarly, industry uncertainty includes input, demand, competition and technological uncertainty, whereas firm uncertainty relates to behavioral, research and development, operating and previous experience uncertainty. The cross-national differences in these two types of uncertainties, coupled with the inconsistencies in the way uncertainty is conceptualized and operationalized, fail to provide a complete picture of the impact of uncertainty on international business performance [24], and national economics with global impact. The scenarios of the future global economic development within the framework of actual crisis development look very uncertain [25].

\section{Conclusion}

The theory of three production sectors and its application to the study of economic development of individual countries is generally accepted. Its validity has been confirmed by long-term statistics. Especially in the second half of the 20th century, together with the development of statistical methods based on the wide possibilities of computer technology and international cooperation of statisticians and economists, the way was opened for a correct assessment of this theory. This also made it possible to apply different views to the whole theory and subsequently formulate its constructive critique by renowned economists.

In conclusion, it appears that the shift to tertiary economies was possible in the western world because other countries could not match their development rate. However, this trend will come to an end when all countries will have reached the economic development step where they could make the transition from industry-based models to service-based ones.

The only way to maintain enough industrial capacity to answer the demand without having some countries lagging behind will be to redistribute the production capabilities among the countries. This would make the economic playfield more even and would also have several side benefits regarding environmental and political issues.

The essence of global trade is changing. Services and the related change in the structure of the economy are gaining in importance, as are China and the countries of South-East Asia. Within the value chains, they move from simple production upwards, they add more value thanks to services. The share of international trade in physical products in global GDP will therefore decrease.

The problem with services is that they are difficult to trade. Moreover, much more than in the case of production, the one who sets the standards has a huge advantage. It is true that, not only because of the current US administration and the mercantilist actions of Beijing and some European countries, we are moving away from global standards, which will complicate and make trade more expensive.

Global cohesion policy should not mean balancing incomes without balancing industrial structures, but also technological and economic progress for lagging countries. This gives us a long way to go.

The global economy is currently battling the Covid pandemic. In industrial production, the pandemic was affected by a shortage of workers due to quarantine. Construction and agriculture also lack casual workers in connection with border closures. The tourism, aerospace and automotive industries are experiencing endless losses. This crisis will affect everyone, every economy will lose $20-25 \%$ of GDP, maybe even $30 \%$. Moreover, after we emerge from this abyss, we are not faced with business as usual, but with a world that will be different in many ways. Something similar has traditionally brought interesting 
opportunities given that, no matter what sector you operate in, the environment around you will undergo structural change, which in many ways means a new start.

\section{References}

1. WTO (2019). Retrieved from: https://www.wto.org/english/res_e /statis_e/wts2019_e/wts2019_e.pdf

2. Remeikienè, R., Belas, J., Kliestik, T., Smrcka, L. (2020). Quantitative Assessment of Dynamics of Economic Development in the Countries of The European Union. Technological and Economic Development of Economy, 26 (4), 933-946.

3. McMillan, M S., Rodrik, D. (2011). Globalization, Structural Change and Productivity Growth. World Development, 63(SI), 11-32.

4. Fisher, A. G.B. (1939). Production, primary, secondary and tertiary. The Economic Record, 15(1), 24-38.

5. Clark, C. (1949). The conditions of economic progress. London: MacMillan and Co Limited.

6. Fourastie, J. (1949). Le Grand Espoir du XXe siècle. Progrès technique, progrès économique, progrès social. Paris: Presses Universitaires de France.

7. Pohl, H.J. (1970). "Kritik der Drei-Sektoren-Theorie," Mitteilungen aus der Arbeitsmarkt- und Berufsforschung. Institut für Arbeitsmarkt- und Berufsforschung (IAB). Nürnberg Institute for Employment Research, 3(4), 313-325.

8. Katouzian, H. (1970). The Developement of the Service Sector: a New Approach. Oxford Economic Papers, 22 (3), 362-382.

9. Palan, N., Schmiedeberg, C. (2010). Structural convergence of European countries. Structural Change and Economic Dynamics, 21, 85-100.

10. European Union (2020). The EU in the world 2020 edition. EU: Eurostat.

11. Valaskova, K., Kliestik, T., Svabova, L., Adamko, P. (2018). Financial Risk Measurement and Prediction Modelling for Sustainable Development of Business Entities Using Regression Analysis. Sustainability, 10, Article Number 2144.

12. United Nations New York (2020). World Economic Situation and Prospects. Retrieved from: $\quad$ https:/www.un.org/development/desa/dpad/wp-content/uploads/sites/ 45/WESP2020_FullReport.pdf

13. Zhang D., Cao H., Zou P. (2016). Exuberance in China's renewable energy investment: rationality, capital structure and implications with firm level evidence. Energy Policy, 95, 468-478.

14. Foure, J., Benassy-Quere, A., Fontagne, L. (2010). The World Economy in 2050: a Tentative Picture. CEPII research center.

15. Lancaster, K. (1980). Intra-industry trade under perfect monopolistic competition. Journal of International Economics, 10 (2), 151-175.

16. Sharmaa, P., Leung, T.Y., Kingshott, R.P.J., Davcik, N.S., Cardinali, S. (2020). Managing uncertainty during a global pandemic: An international business perspective. Journal of Business Research, 116, 188-192.

17. Jones, C.I. (2016). Chapter 1 - The Facts of Economic Growth. Handbook of Macroeconomics. Retrieved from: https://web.stanford.edu/ chadj/facts.pdf. 
18. Kliestik, T., Valaskova, K., Nica, E., Kovacova, M., Lazaroiu, G. (2020). Advanced methods of earnings management: monotonic trends and change-points under spotlight in the Visegrad countries. Oeconomia Copernicana, 11(2), 371-400.

19. Iuorio O., Wallace A., Simpson K. (2019). Prefabs in the North of England: technological, environmental, and social innovations. Sustainability, 11(14), 3884.

20. Haraguchi, N., Martorano, B., Sanfilippo, M. (2019). What factors drive successful industrialization? Evidence and implications for developing countries. Structural Change and Economic Dynamics, 49(C), 266-276.

21. Evans, O. (2020). Socio-economic impacts of novel coronavirus: The policy solutions. BizEcons Quarterly, Strides Educational Foundation, 7, 3-12.

22. Hosseini, S.E. (2020). Perspective An outlook on the global development of renewable and sustainable energy at the time of COVID-19. Direct Energy Research \& Social Science journal, 68, 101633.

23. Baumer-Cardoso, M., Campos, L., Santos, P., Frazzon, E. (2020). Simulation-based analysis of catalyzers and trade-offs in lean and Green manufacturing. Journal of Cleaner Production, 242, Article Number 118411.

24. Sniazhko, S. (2019). Uncertainty in decision-making: A review of the international business literature. Cogent Business \& Management, 6 (1), Article Number 1650692.

25. Civín, L., Smutka, L. (2020). Vulnerability of European Union Economies in Agro Trade. Sustainability, 12(12), Article Number 5210. 